\title{
Applications of Pulsed Neural Network Incorporating Short Term Synaptic Plasticity to Autonomous Mobile Robots
}

\author{
Makoto Motoki Member (Kanto Gakuin University, motoki@kanto-gakuin.ac.jp) \\ Seiichi Koakutsu Member (Chiba University, koakutsu@faculty.chiba-u.jp) \\ Hironori Hirata Member (Chiba University, hiro@faculty.chiba-u.jp)
}

Keywords: neural network, pulsed neuron, genetic algorithms, autonomous mobile robot

We compare the performance of four types of controllers for an autonomous mobile robot through computer simulation. Each controller consists of different kinds of architectures of neural networks (NN). Four types of NNs are as follows: Sigmoid NN, Radial NN, pulsed NN (PNN), and PNN incorporating short term synaptic plasticity (PNNSSP). In computer simulation, parameters of NNs are adjusted using genetic algorithm. Fig.1 4 and Table 1 show the results of computer simulation. The results show that PNNSSP is more efficient than others for the controller of the autonomous mobile robot.

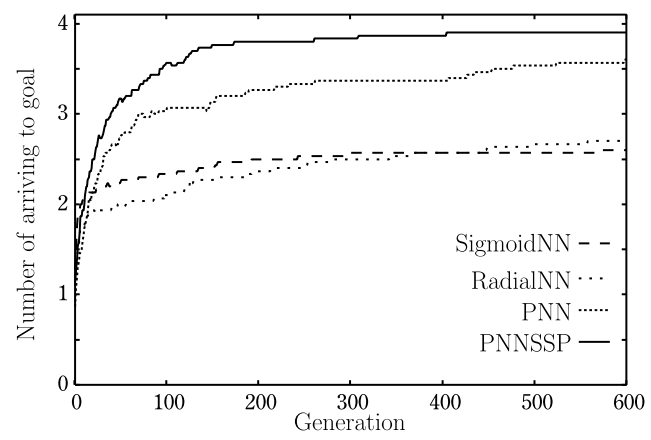

Fig. 1. Generation characteristic of quantity whose robot arrived to goal
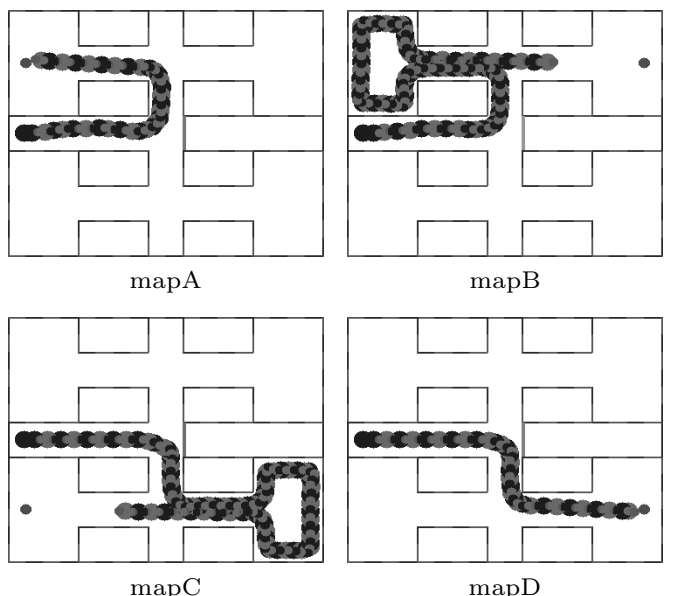

Fig. 2. Trace of robot whose controller is Sigmoid NN. Task is failuer. Fitness is 389

Table 1. The number of neurons and synapses of hidden layer

\begin{tabular}{|l||c|c|c||c|c|c|}
\hline \multicolumn{1}{|c||}{} & \multicolumn{3}{c||}{ Neurons } & \multicolumn{3}{c|}{ Synapses } \\
\cline { 2 - 7 } & max. & average & min. & max. & average & min. \\
\hline Sigmoid NN & 17 & 13.5 & 10 & 220 & 203.3 & 185 \\
\hline Radial NN & 15 & 11.2 & 8 & 229 & 182.7 & 149 \\
\hline PNN & 17 & 14.0 & 11 & 238 & 211.3 & 152 \\
\hline PNNSSP & 15 & 11.9 & 5 & 219 & 175.0 & 91 \\
\hline
\end{tabular}

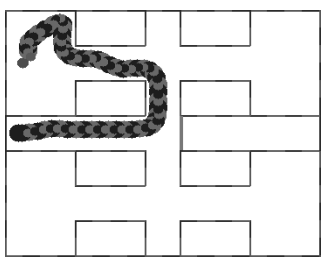

mapA

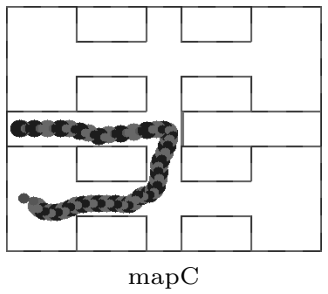

Fig. 3. Trace of robot whose controller is PNN. Task is success. Fitness is 512. The number of hidden layer's neurons is 14 and that of synapses is 199
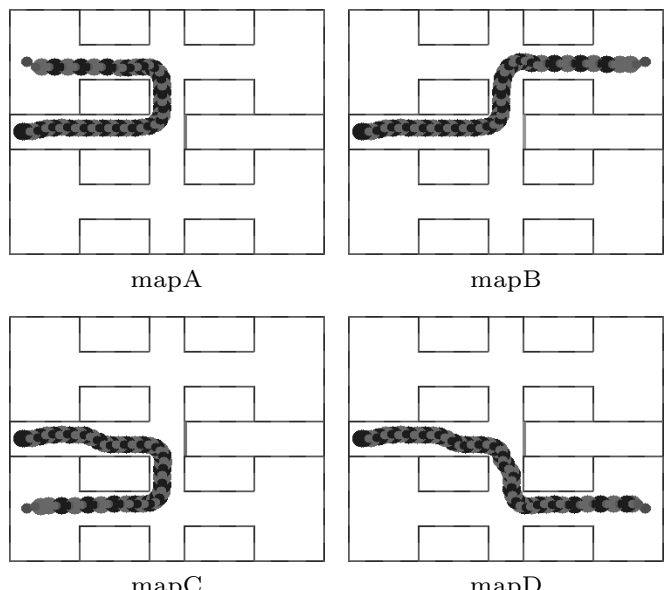

Fig. 4. Trace of robot whose controller is PNNSSP. Task is success. Fitness is 746 . The number of hidden layer's neurons is 9 and that of synapses is 140 


\title{
短期的な伝達効率の調節機構を持つ \\ パルスニューラルネットワークの 自律移動ロボットへの応用
}

\author{
正員 元木 誠* 正 員 小圷 成一** \\ 正 員 平田 廣則**
}

\begin{abstract}
Applications of Pulsed Neural Network Incorporating Short Term Synaptic Plasticity to Autonomous Mobile Robots
\end{abstract}

Makoto Motoki*, Member, Seiichi Koakutsu**, Member, Hironori Hirata**, Member

We compare the performance of four types of controllers for an autonomous mobile robot through computer simulation. Each controller consists of different kinds of architectures of neural networks (NN). Four types of NNs are as follows: Sigmoid NN, Radial NN, pulsed NN (PNN), and PNN incorporating short term synaptic plasticity (PNNSSP). In computer simulation, parameters of NNs are adjusted using genetic algorithm. The results of computer simulation show that PNNSSP is more efficient than other typs of NNs for the controller of the autonomous mobile robot.

キーワード：ニューラルネットワーク，パルスニューロン，遺伝的アルゴリズム，自律移動ロボット

Keywords: neural network, pulsed neuron, genetic algorithms, autonomous mobile robot

\section{1. まえがき}

近年，自律移動ロボットのコントローラを遺伝的アルゴ リズム (Genetic Algorithms: GA) (1) や強化学習等の機 械学習や生物の神経細胞ネットワークを模倣したニューラ ルネットワーク（Neural Network: NN）を用いて，ボト ムアップ的に構築する手法が研究されている。本論文では, これらの手法の中で, NN によるコントローラの構築に着 目する。

従来, 自律移動ロボットのコントローラに使用する NN は, ニューロンの出力をシグモイド関数や球形基底関数等 を用いて，連続值で表現するアナログニューロン（Analog Neuron）モデル（以下， AN モデル）で構築されたネット ワークが使用されている。しかしながら，AN モデルの式に

\footnotetext{
$*$ 関東学院大学

干 236-8501 神奈川県横浜市金沢区六浦東 1-50-1

Kanto Gakuin University,

1-50-1 Mutsuurahigashi, Kanazawa-ku, Yokohama-shi, Kanagawa, 236-8501

** 千葉大学

干 263-8522 千葉県千葉市稲毛区弥生町 1-33

Chiba University,

1-33 Yayoi-cho, Inage-ku, Chiba-shi, Chiba, 263-8522
}

は時間に関する項が含まれないため時間軸を考慮した制御 が難しく，そのような制御を行うためには，ネットワーク構 造をリカレント型，もしくは相互結合型にするか，ネット ワークへの入力として数ステップ前までのセンサ值を入力 しなければならない。そのため, ネットワークの規模が大き くなり, ニューロンのパラメータ設定, 及びネットワーク構 造の決定が困難になる。この問題点を解決するために, 減衰 のある積分発火ニューロン (Integrate-and-Fire neuron) モデル (以下, IF モデル) (2) で構築されたパルスニューラ ルネットワーク (Pulsed Neural Network : PNN) (3) (4) をコントローラに用いることが考えられる。PNN は, モデ ルの式に時間に関する項が含まれているため時系列処理に 適しているといえ, PNN をロボットのコントローラに用 いる場合，ネットワークへの入力である各センサ值の時間 的変化を考慮した出力が可能となる ${ }^{(5)}$ 。その結果, 時間軸 を考慮した制御が可能になり，またネットワークの規模も 大きくする必要がないため，ニューロンのパラメータ，及 びネットワーク構造の決定が容易になると考えられる。

本論文では, PNNを拡張する形で我々が提案している短期 的な伝達効率の調整機構を組み込んだ PNN (Pulsed Neural Network incorporating Short term Synaptic Plasticity: PNNSSP) (6) を, 時系列処理が必要な自律移動ロボットの 
コントローラの構築に応用し，PNNSSP のコントローラと しての有効性を検証する。具体的には, 自律移動ロボットの コントローラの構成法として, NN の構造と重みを GAに より最適化することで構築する場合において，アーキテク チャの異なる 4 種類の NN について, コントローラ構築の 容易さ，及び性能を比較する計算機実験を行う。これらの 計算機実験を通して，ニューロンの出力にシグモイド関数 を用いる NN (Sigmoid NN)，及び中間層のニューロンの 出力に球形基底関数 (Radial Basis Function: RBF) を用 いる NN (Radial NN) よりも, PNN, 及びPNNSSP の 方が, コントローラの構築が容易で, 性能が優れているこ とを示し，また，PNN に比べて PNNSSP の方が，ニュー ロン数, 及びシナプス数が少なく, ネットワーク構造が単 純になることを示す。以上により, PNNSSP が自律移動 ロボットのコントローラとして優れていることを明らかに する。

以降， 2 章では本論文で扱う各種 $\mathrm{NN}$ モデルについて，3 章では本論文で扱う NN による自律移動ロボットのコント ローラの構築について述べ，4章では計算機実験について述 ベる。最後に 5 章で本論文を総括し, 今後の課題を述べる。

\section{2. 各種ニューラルネットワーク}

本論文で扱う各種 NN モデルについて説明する。なお， ネットワークは出力層, 隠れ層, 入力層の 3 層構造とし, ニューロン $j$ をシナプス後ニューロン（以降, 後ニューロ ン), ニューロン $k$ をシナプス前ニューロン（以降, 前ニュー ロン）とする。

〈2・1〉 Sigmoid NN Sigmoid NN はニューロンの 入力を（1）式で計算し，(2) 式に示すシグモイド関数を ニューロンの出力に用いる。

$$
\begin{aligned}
x^{j} & =\sum_{k \in K} w_{0}^{j, k} y^{k} \ldots \ldots \ldots \ldots \\
y^{j} & =\frac{1}{1+\exp \left(-\beta^{j}\left(x^{j}+\theta^{j}\right)\right)}
\end{aligned}
$$

ここで, $x^{j}$ は後ニューロン $j$ の入力, $w_{0}^{j, k}$ は前ニューロ ン $k$ と後ニューロン $j$ 間の結合荷重， $K$ は前ニューロン $k$ の集合, $y^{k}$ は前ニューロン $k$ の出力, $y^{j}$ は後ニューロン $j$ の出力, $\beta^{j}$ は後ニューロン $j$ におけるシグモイド関数の 傾き， $\theta^{j}$ は後ニューロン $j$ の閾值である。また，本論文で は, $-1 \leq w_{0}^{j, k} \leq 1$ とする。

〈2・2〉 Radial NN Radial NNは（3）式を隠れ層 のニューロンの入力とし，(4) 式を隠れ層のニューロンの 出力に用いる。

$$
\begin{aligned}
& x^{j}=\sum_{k \in K}\left(\frac{y^{k}-\mu^{j, k}}{\sigma^{j, k}}\right)^{2} \\
& y^{j}=\exp \left(-\frac{x^{j}}{2}\right) \cdots \cdots
\end{aligned}
$$

ここで， $\mu^{j, k}$ は後ニューロン $j$ における前ニューロン $k$ の 出力 $y^{k}$ の代表值, $\sigma^{j, k}$ は後ニューロン $j$ と前ニューロン $k$ 間の標準偏差である。なお，隠れ層のニューロン以外は Sigmoid NN と等しい。

〈2·3〉 PNN PNNの基本的ニューロンモデルは, IF モデルである。なお，本論文では計算機によるソフト ウェア実装を前提とするため, 各式は実装する際に離散化 される。時刻 $t$ も離散值となり, 離散化する際の時間の刻 み幅を $\Delta t$ とする。前ニューロン $k$ の発火時刻の集合 $T^{k}$ を（5）式のように表す。

$$
T^{k}=\left\{t_{\nu}^{k} ; \nu \in\left\{1, \ldots, n^{k}\right\}\right\}=\left\{t \mid y^{k}(t)=1\right\}
$$

ここで, $t_{\nu}^{k}$ は前ニューロン $k$ の $\nu$ 番目の発火時刻, $n^{k}$ は ニューロン $k$ の発火回数, $y^{k}(t)$ は時刻 $t$ におけるニューロ ン $k$ の出力である。

後ニューロン $j$ に前ニューロン $k$ のパルスが到達する時 刻の集合 $T_{\mathrm{d}}^{j, k}$ は $(6)$ 式のように表せる。

$$
T_{\mathrm{d}}^{j, k}=\left\{t_{\mathrm{d}, \nu}^{j, k}=t_{\nu}^{k}+\tau_{\mathrm{d}}^{j, k} ; \nu \in\left\{1, \ldots, n^{k}\right\}\right\} \cdots
$$

ここで, $t_{\mathrm{d}, \nu}^{j, k}$ は前ニューロン $k$ で発生した $\nu$ 番目のパルス が後ニューロン $j$ に到達する時刻, $\tau_{\mathrm{d}}^{j, k}$ は前ニューロン $k$ で発生したパルスが後ニューロン $j$ に到達するまでの時間 遅れである。

パルスが到達すると, 後ニューロン $j$ の膜電位 $P_{\mathrm{m}}^{j}(t)$ は, （7）式により変化する。

$$
\tau_{\mathrm{m}}^{j} \frac{d P_{\mathrm{m}}^{j}(t)}{d t}=-P_{\mathrm{m}}^{j}(t)+\sum_{k \in K} w_{0}^{j, k} \sum_{t_{\mathrm{d}, \nu}^{j, k} \in T_{\mathrm{d}}^{j, k}} \delta\left(t-t_{\mathrm{d}, \nu}^{j, k}\right)
$$

ここで, $\tau_{\mathrm{m}}^{j}$ は減衰時定数, $\delta(\cdot)$ は Dirac のデル夕関数で ある。

膜電位 $P_{\mathrm{m}}^{j}(t)$ が䦨值 $\theta^{j}$ を越えると, 後ニューロン $j$ は 発火する。ニューロン $j$ の出力 $y^{j}(t)$ を, (8) 式のように表 す。また，二ューロン $j$ の発火時刻を表す集合 $T^{j}$ は, (9) 式のようになる。

$$
\begin{aligned}
& y^{j}(t)=\mathcal{H}\left(P_{\mathrm{m}}^{j}(t)-\theta^{j}\right) \cdots \cdots \cdots \cdots \cdots \cdots \cdots \\
& T^{j}=\left\{t_{\nu}^{j} ; 1 \leq \nu \leq n^{j}\right\}=\left\{t \mid y^{j}(t)=1\right\} \cdots \cdots
\end{aligned}
$$

ここで, $\mathcal{H}(\cdot)$ はへビサイド関数である。ニューロン $j$ が 発火した場合, 膜電位 $P_{\mathrm{m}}^{j}(t)$ は, 不応期 $\tau_{\mathrm{r}}^{j}$ の間 0 となる。 また，本論文では $\Delta t \leq \tau_{\mathrm{d}}^{j, k}<\tau_{\mathrm{r}}^{k}$ とする。

〈2・4〉 PNNSSP 実ニューロンにおいて前ニューロ ンからのパルス頻度による短期的に伝達効率が変化するこ とを短期的シナプス可塑性 (7) という。この短期的シナプス 可塑性は短期抑圧（Short Term Depression：STD）と短 期増強（Short Term Potentiation：STP）に分類される。 STD は, 前ニューロンのパルス頻度が上昇すると後ニュー ロンの反応が順次減少し, 前ニューロンのパルス頻度が元 に戻ると後ニューロンの反応も数秒後に元に戻るという現 象をいい, 大脳皮質内の錐体細胞から錐体細胞へのシナプ 
ス結合や視覚野の IV 層から II / III 層への興奮性シナプス 結合でみられる。また STP は，前二ューロンのパルス頻度 が上昇すると後ニューロンの反応が順次増加し, 前ニュー ロンのパルス頻度が元に戻ると後ニューロンの反応も数秒 後に元に戻るという現象をいい，大脳皮質内の錐体細胞か ら抑制性介在細胞へのシナプス結合，海馬 CA3 領域の錐 体細胞から海馬 CA1 領域の錐体細胞へのシナプス結合や 歯状回顆粒細胞から CA3 錐体細胞へのシナプス結合でみ られる。

〈2・3〉節で述べた PNN モデルでは，実ニューロンとは異 なり興奮性シナプス結合 $\left(w_{0}^{j, k}>0\right)$ の場合には, 前ニュー ロン $k$ のパルス頻度が上昇すると後ニューロン $j$ のパルス 頻度も上昇する。これは, 実ニューロンにおける短期的シ ナプス可塑性のような機構が組み込まれていないためであ る。実ニューロンのように，前ニューロン $k$ のパルス頻度が 上昇した場合に後ニューロン $j$ のパルス頻度を減少させる 場合は，新たにニューロン $l$ を設け，ニューロン $l$ とニュー ロン $j$ を抑制性シナプス $\left(w_{0}^{j, l}<0\right)$ で結合する。そして, ニューロン $l$ はニューロン $k$ と興奮性シナプス $\left(w_{0}^{l, k}>0\right)$ で結合し，ニューロン $j$ のパルス頻度とは異なる頻度で発 火させなければならない。そのため, 複雑な情報処理を行 わせる場合，ネットワークのニューロン数，及びシナプス 数が増加し, 構造も複雑になる傾向がある。つまり, 前述 したPNN モデルは 1 個のニューロンあたりの情報処理能 力が小さいという問題点がある。そこで，PNN に実ニュー ロンで行われる短期的シナプス可塑性のような短期的な伝 達効率の調節機構を付加すれば， 1 個のニューロンあたり の情報処理能力が向上し，ネットワークのニューロン数の 増加, 及び構造の複雑化を抑制することが可能になると考 えられる。

PNN における 1 個のニューロンあたりの情報処理能力 が小さいという問題を解決するために（7）式を（10）式〜 (14) 式のように拡張する。

$$
\tau_{\mathrm{m}}^{j} \frac{d P_{\mathrm{m}}^{j}(t)}{d t}=-P_{\mathrm{m}}^{j}(t)+\sum_{k \in K} w^{j, k}(t) \sum_{t_{\mathrm{d}, \nu}^{j, k} \in T_{\mathrm{d}}^{j, k}} \delta\left(t-t_{\mathrm{d}, \nu}^{j, k}\right)
$$

$t \neq t_{\mathrm{d}, \nu}^{j, k}+\Delta t$ の場合

$$
\begin{aligned}
& w^{j, k}(t)=w_{\mathrm{std}}^{j, k}(t)+w_{\mathrm{stp}}^{j, k}(t) \ldots \ldots \ldots \ldots \ldots \ldots \\
& \tau_{\mathrm{std}}^{j, k} \frac{d w_{\mathrm{std}}^{j, k}(t)}{d t}=-w_{\mathrm{std}}^{j, k}(t)+w_{0}^{j, k} \ldots \ldots \ldots \ldots \ldots \\
& \tau_{\mathrm{stp}}^{j, k} \frac{d w_{\mathrm{stp}}^{j, k}(t)}{d t}=-w_{\mathrm{stp}}^{j, k}(t)-\eta^{j, k} w_{0}^{i, j} \ldots \ldots \ldots \ldots
\end{aligned}
$$

$t=t_{\mathrm{d}, \nu}^{j, k}+\Delta t$ の場合

$$
w^{j, k}(t)=w_{\mathrm{std}}^{j, k}(t)=w_{\mathrm{stp}}^{j, k}(t)=0 \cdots
$$

ここで, $w^{j, k}(t)$ は時刻 $t$ における結合荷重, $\tau_{\mathrm{std}}^{j, k}$ は短期 抑制時定数, $\tau_{\mathrm{stp}}^{j, k}$ は短期増強時定数, $\eta^{j, k}$ は短期増強率 $\left(0 \leq \eta^{j, k} \leq 1\right)$ である。これにより，結合荷重 $w_{0}^{j, k}$ が時
間の関数 $w^{j, k}(t)$ に拡張され, PNN に実ニューロンで行わ れる短期的シナプス可塑性のような短期的な伝達効率の調 節機構が組み込むことが可能となる。

$\operatorname{PNNSSP}$ における $w^{j, k}(t)$ は, 時刻 $t$ で前ニューロンの シナプス終末部のシナプス小胞から放出可能な伝達物質量, 及び後ニューロンの受容体で受容可能な伝達物質量として いる。シナプスには電気シナプスと化学シナプスがあるが, 本論文では化学シナプスだけを考える。また，伝達物質の 放出確率 (8) は導入していない。 $t=t_{\mathrm{d}, \nu}^{j, k}$ (後ニューロン $j$ に前ニューロン $k$ からのパルスが到達する時刻）において， 放出可能な伝達物質量及び受容可能な伝達物質量をすべて 放出, または受容する。そのため, つぎの時刻 $t=t_{\mathrm{d}, \mu}^{j, k}+\Delta t$ で放出可能な伝達物質量, 及び受容可能な伝達物質量は, 式 (14) のように $w_{\mathrm{std}}^{j, k}(t), w_{\mathrm{stp}}^{j, k}(t)$, 及び $w^{j, k}(t)$ がすべて 0 に なる。その後, $w^{j, k}(t)$ は時定数 $\tau_{\mathrm{std}}^{j, k}, \tau_{\mathrm{stp}}^{j, k}$ で回復する。再 び前ニューロンが発火し，後ニューロンにそのパルスが到 達する時刻で放出可能な伝達物質量及び受容可能な伝達物 質量をすべて放出，または受容し，つぎの時刻での $w^{j, k}(t)$ は 0 になる。

PNNSSP において, $\tau_{\text {std }}^{j, k}>\tau_{\text {stp }}^{j, k}$ のときシナプスは STD の性質を持ち，前ニューロンのパルス頻度が上昇するにつ れて, $w^{j, k}(t)$ は減少する。例えると, ローパスフィルタの 周波数特性のような性質を持つ。逆に, $\tau_{\mathrm{std}}^{j, k}<\tau_{\mathrm{stp}}^{j, k}$ のとき シナプスはSTP の性質を持ち, 前ニューロンのパルス頻度 が上昇するにつれて, $w^{j, k}(t)$ はあるパルス頻度までは増加 し, さらに前ニューロンのパルス頻度が上昇すると $w^{j, k}(t)$ は減少する。この場合は, バンドパスフィルタの周波数特性 のような性質を持つ。また, STP の性質を持つとき $\eta^{j, k}$ を 大きくすると，より特定のパルス頻度のときたけ， $w^{j, k}(t)$ が上昇するようになる。このように, PNNSSP は $\tau_{\mathrm{std}}^{j, k}, \tau_{\mathrm{stp}}^{j, k}$ の大小関係，及び $\eta^{j, k}$ の值により，シナプスの性質を変化 させることが可能である。しかしながら，実ニューロンで は，1個のシナプスが STD, STP の両方の性質を持つよう なことはない。PNNSSP は実ニューロンのモデル化が目的 ではなく, 工学的応用を目的としている点に留意されたい。

\section{3. ニューラルネットワークによる自律移動ロボット のコントローラの構築}

NN による自律移動ロボットのコントローラの構築につ いて説明する。本論文では, 自律移動ロボットに異なる数種 類の環境中を走行させ，それぞれのスタート地点からゴー ル地点まで移動させることをロボットのタスクとする。

Sigmoid NN, Radial NN, PNN，及びPNNSSP をコ ントローラに用いる場合について, 各パラメータの調整, 及 びネットワークの構造決定に GA を用いる際のコントロー ラの構築のしやすさ, ロボットのタスクの達成度合等の性 能, 及び構築されたネットワーク構造の複雑さを比較する。

なお，文献（6）においても PNN, PNNSSP を自律移動 ロボットのコントローラに用いる比較計算機実験を行って る。本論文と文献（6）の違いは, PNN, PNNSSP に加え, 


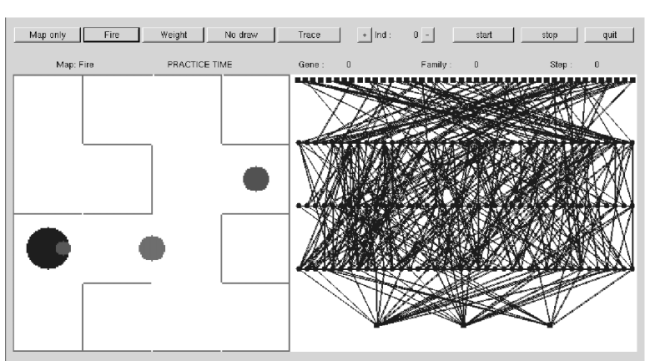

図 1 自律移動ロボットシミュレータ

Fig. 1. Autonomous mobile robot simulator.

AN モデルを用いたSigmoid NN，Radial NN についても 比較する点，環境が異なる点，〈3・1 節で説明する移動モ ジュールが異なる点, ネットワーク構造も GA で決定し構 築された構造を比較する点である。

〈3・1 $\quad$ 自律移動ロボットシミュレータ 実験環境とし て図 1 に示寸自律移動ロボットシミュレー夕を使用する。 このシミュレータは独自に開発したもので，以下のような 特徽がある。1.リアルタイムに NN の動作を確認可能。2. ロボットは円形で，大きさを任意に設定可能。3. 左右の車 輪を駆動するモータへの出力を制御することでロボットの 移動が可能。4. ロボットの行動フィールド（マップの大き さ，障害物等）を任意に設定可能。5. 近接センサを搭載し， 反応半径，搭載個数を任意に設定可能。6. 視覚センサを搭 載し，解像度，搭載個数を任意に設定可能。

また，本論文では左右の車輪を駆動するモータへの出力 の值を, 直接制御するのではなく, あらかじめ設計した移 動モジュールを選択することによりロボットを移動させる。 本論文では移動モジュールとして, 前進, 右壁沿い, 左壁沿 いの 3 種のモジュールを用意する。前進モジュールは，車輪 を駆動する左右のモータへ等しい值を出力するモジュール であり，右壁沿い，左壁沿いモジュールは，それぞれロボッ トの右側の壁，または左側の壁に沿って移動するモジュー ルあり， AN モデルを用いる 2 層の NN で設計されている。 な抢，本論文では車輪の空転や滑走はないとして，移動モ ジュールを設計している。

本実験では前進モジュールの移動速度を $0.3[\mathrm{~m} / \mathrm{s}]$, 壁 沿い行動の最大速度を $0.2[\mathrm{~m} / \mathrm{s}]$ に設定する。ロボットは 左右の壁沿い行動でも前進できる。しかし, 前進モジュー ルを選択した方がより速く移動できる。

移動モジュールの選択は，後述するコントローラである $\mathrm{NN}$ に扔ける出力層の 3 個のニューロンからの出力により決 定される。Sigmoid NN, 及び Radial NN は 3 個のニュー ロンの出力值で最も大きいニューロンに対応するモジュー ルを選択する。ただし, 最も大きい出力值が 2 個以上ある 場合はモジュールを選択せず，その場で停止する。PNN， 及びPNNSSP は 3 個のニューロンの出力值のうち，1個た け発火している場合にそのニューロンに対応するモジュー ルを選択する。2 個以上のニューロンが発火している場合は その場で停止する。また，どのニューロンも発火していな
い場合は，1ステップ前に選択したモジュールを選択する。 近接センサ, 及び視覚センサについて説明する。近接セ ンサの值は $0 \sim 1$ の実数值とし, 障害物が近いほどセンサ 值は大きくなる。視覚センサも值は $0 \sim 1$ の実数值とし, 壁, ゴール地点, 及び指示板等に固有の值を人手により割 り当てる。Sigmoid NN, 及び Radial NN では, 近接セン サ，及び視覚センサの值が対応する入力層のニューロンへ （15）式により入力される。

$$
x^{i}(t)=S^{i}(t)+\alpha_{\mathrm{ns}} S_{\mathrm{ns}}^{i}(t) .
$$

ここで, $S^{i}(t)$ は時刻 $t$ に㧍ける入力層のニューロン $i$ が対 応する近接センサもしくは視覚センサの値, $S_{\mathrm{ns}}^{i}(t)$ は時刻 $t$ に扔ける入力層のニューロン $i$ が対応する近接センサも しくは視覚センサの外乱 $(0 \sim 1$ の実数值 $), \alpha_{\mathrm{ns}}$ は外乱の 大きさである。

これに対し，PNN と PNNSSP の入力はパルスであり， 実数值をそのまま入力できないので，七ンサに対応する入 力層のニューロン $i$ の入出力を $(16),(17)$ 式により計算 する。

$$
\begin{aligned}
& y^{i}(t)=\mathcal{H}\left(x^{i}(t)-1\right) \ldots \ldots \ldots \ldots \ldots \ldots \ldots \ldots \\
& x^{i}(t)=x^{i}(t-\Delta t)+\frac{S^{i}(t)+\alpha_{\mathrm{ns}} S_{\mathrm{ns}}^{i}(t)}{\tau_{\mathrm{r}}^{i} / \Delta t+1} \cdots \cdots
\end{aligned}
$$

ここで, $\tau_{\mathrm{r}}^{i}$ はニューロン $i$ の不応期である。

なお，本論文では（15），(16）式の $\alpha_{\mathrm{ns}}$ を 0 とし，外 乱を加えないこととする。

〈3・2〉 遺伝的アルゴリズムによるネットワークの調整 自律移動ロボットのコントローラとして NNを使用する 場合, ニューロン, 及びシナプスの個数が多くなる。その ため, トップダウン的にニューロン，及びシナプスの各パ ラメータを適切に設定することは困難となる。そこで, 最 適化手法のひとつである GA を用いてニューロン, 及びシ ナプスのパラメータを設定する。また，NNをハードウェ ア化する場合, ハードウェア化が容易な PNN と GA を組 み合わせ，FPGA 等の再構成が可能なデバイスに搭載する ことで, 進化型ハードウェアを構築することが可能になる と考えらる。

ニューロンのパラメータ，及びシナプスのパラメータを 実数值として並べた二本の一次元配列を染色体とする。染 色体のニューロンに関する部分とシナプスに関する部分は, 別々に遺伝操作を施す。なお，染色体となるパラメー夕は, ニューロンの種類や各実験で異なり, 4 . 計算機実験で具体 例を示す。

遺伝的操作には，二点交叉と突然変異を用いる。世代交 代は，集団 $N$ 個体中，適応度の高い順に $E_{\mathrm{n}}$ 個体を保存し， そのまま次世代に残す。ここで, 保存の対象となる個体と 適応度が等しい個体が複数ある場合, 遺伝子に多様性を持 たせるため，ランダムに選択した一個体だけ保存し，つぎ に適応度が高い個体を順次保存する。また, 前世代で保存 した個体が保存の対象となる場合で, 前世代で保存した個 
体と適応度が等しい個体が複数存在するとき，進化の停滞 を防ぐため, 前世代で保存した個体は保存の対象から除く。 残りの個体を交叉率 $C_{\mathrm{r}}$ で交叉を行う。交叉を行う際，適応 度に基づきルーレット選択により親個体を選択する。また， 染色体を複製する際に，ニューロン，及びシナプス一個に つき，突然変異率 $C_{\mathrm{m}}$ で突然変異を施し，新たなニューロ ン，及びシナプスを生成する。

〈3·3〉 実験手順＼cjkstart実験の手順を以下に示す。

（1）初期集団を $N$ 個体生成する。

（2）各環境（mapA〜mapD）において，すべてのロ ボットを規定ステップ数走行させる。壁に衝突し た場合は，その環境における走行を終了する。

（3）適応度に基づき遺伝的操作を施し, 新集団を生成 する。

（4）規定世代数 $G_{\max }$ まで手順 $(2),(3)$ を繰り返す。 ここでいう，ステップとは時間の刻み幅 $\Delta t$ に等しく，規 定ステップ数を 400 ステップとする。

\section{4. 計算機実験}

図 2 に示す mapA 〜 mapD の 4 種類の環境を自律移動 ロボットに走行させ，それぞれのスタート地点からゴール 地点まで移動させることをロボットのタスクとする計算機 実験を行う。この実験では, Simgmoid NN, Radial NN, $\mathrm{PNN}$, 及び PNNSSP のパラメー夕調整に GA を用いる場 合において，コントローラの構築のしやすさ，ロボットの夕 スクの達成度合, 及びロボットの行動軌跡, 構築されたネッ トワークの複雑さを比較する。図 2 中の mapA $\sim \operatorname{mapD}$ の左側の円がロボットで，ロボットのいる地点がスタート 地点となり, mapA の左側上, $\operatorname{mapB}$ の右側上, $\operatorname{mapC} の$ 左側下， mapD の右側下の円がゴール地点である。また, mapA〜mapD の中央部に指示板がある。指示板は環境ご とに色が異なり，スタート地点からみた各環境の違いは指 示板の色だけである。なお，ロボットがスタート地点に停

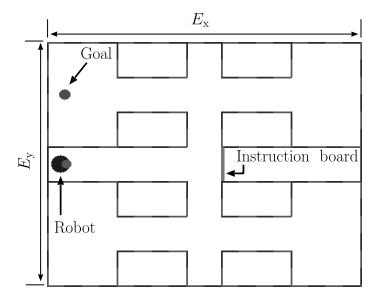

mapA

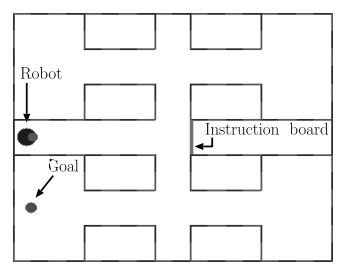

mapC

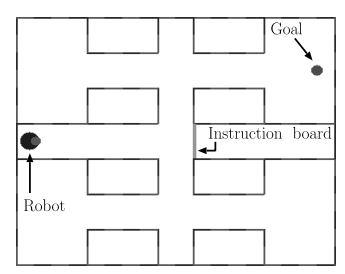

$\operatorname{mapB}$

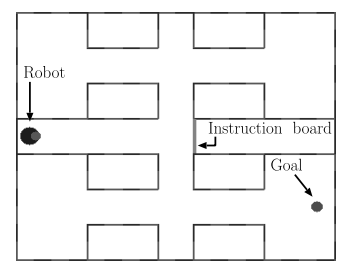

mapD
図 2 環境

Fig. 2. Environments
止している状態から実験を開始する。

本実験では，図 3 に示すようなロボットを想定しており， 自律移動ロボットシミュレータの環境の大きさ $E_{\mathrm{x}} \times E_{\mathrm{y}}$ を $360 \times 280[\mathrm{~cm}]$, ロボットの半径 $R_{\mathrm{b}}$ を $10[\mathrm{~cm}]$, 近接セン サを 8 個搭載, 近接センサ反応距離 $R_{\mathrm{p}}$ を $20[\mathrm{~cm}]$, 視覚 センサを 1 個搭載, 視覚センサ解像度 12 [bit], 視覚セン サ反応角 $\theta_{\mathrm{v}}$ を 45 [deg.], 視覚センサ反応半径 $R_{\mathrm{v}}$ を 300 $[\mathrm{cm}]$ とする。

また，視覚センサの值の割り当ては，ゴールの值を 1.0 , 壁の值を 0.063 と 0.250 (図 2 では見難いが $20[\mathrm{~cm}]$ ごとに色 分けされている)， mapAの指示版の值を $0.375, \operatorname{mapB}$ の 指示版の值を 0.500 , mapC の指示版の值を $0.750, \mathrm{mapD}$ の指示版の值を 0.625 とする。

構築されたネットワークの構造の複雑さを比較するため に，一つのニューロンが次層のニューロンすべてにシナプ スを形成するのではなく，ネットワーク全体で形成できる シナプス数を制限する。なお，本実験では最大シナプス数 を 250 個とする。GA により，シナプスの接続元のニュー ロン，接続先ニューロンに加えて，そのシナプスを使用す るか否かをニューロン，及びシナプスのパラメータととも に決定する。したがって, 本実験における染色体となる各 $\mathrm{NN}$ のパラメータは以下のようになる。

- Sigmoid NN

ニューロン : $\theta^{j}, \beta^{j}$

シナプス：前ニューロン番号, 後ニューロン番号, $w_{0}^{j, k}$, 使用の可否

- Radial NN

ニューロン: $\theta^{j}, \beta^{j}$ (入力層と出力層のみ)

シナプス : 前ニューロン番号, 後ニューロン番号, $\mu^{j, k}, \sigma^{j, k}$ ，使用の可否

(入力層と隠れ層間),

前ニューロン番号, 後ニューロン番号, $w_{0}^{j, k}$, 使用の可否

(隠れ層と出力層間)

\section{- $\mathrm{PNN}$}

ニューロン : $\tau_{\mathrm{m}}^{j}$

シナプス：前ニューロン番号, 後ニューロン番号, $\tau_{\mathrm{d}}^{j, k}, w_{0}^{j, k}$, 使用の可否

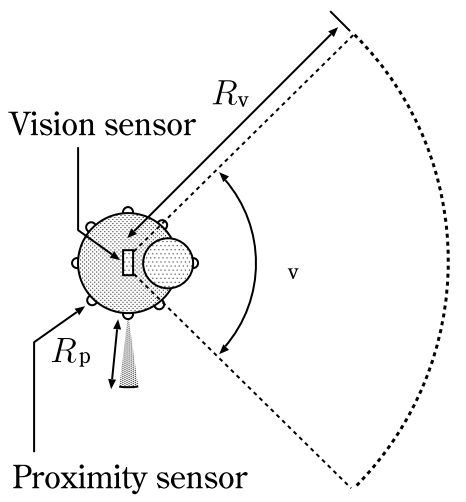

困 3 自律移動ロボット

Fig. 3. Autonomous mobile robot. 
表 1 Sigmoid NN, Radial NN のパラメータ

Table 1. Parameters for Sigmoid NN and Radial NN

\begin{tabular}{|c||r|c|}
\hline & Sigmoid NN & Radial NN \\
\hline$\theta^{j}$ & $0.1 \sim 0.9$ \\
\hline$\beta^{j}$ & \multicolumn{2}{|c|}{$1.0 \sim 8.0$} \\
\hline$w_{0}^{j, k}$ & $-1.00 \sim 1.00$ \\
\hline$\mu^{j, k}$ & - & $0.0 \sim 1.0$ \\
\hline$\sigma^{j, k}$ & - & $0.1 \sim 1.0$ \\
\hline
\end{tabular}

表 2 PNN, PNNSSP のパラメータ

Table 2. Parameters for PNN and PNNSSP

\begin{tabular}{|c||r|r|}
\hline & PNN & PNNSSP \\
\hline$\Delta t[\mathrm{~s}]$ & \multicolumn{2}{|c|}{0.1} \\
\hline$\theta^{j}$ & \multicolumn{2}{|c|}{0.01} \\
\hline$\tau_{\mathrm{r}}^{r}[\mathrm{~s}]$ & \multicolumn{2}{|c|}{0.5} \\
\hline$\tau_{\mathrm{m}}^{j}[s]$ & $0.5 \sim 3.0$ & $1.5 \sim 3.0$ \\
\hline$\tau_{\mathrm{d}}^{j, k}[\mathrm{~s}]$ & \multicolumn{2}{|c|}{$0.1 \sim 0.4$} \\
\hline$w_{0}^{j, k}$ & \multicolumn{2}{|c|}{$-1.00 \sim 1.00$} \\
\hline$\tau_{\mathrm{std}}^{j, k}[\mathrm{~s}]$ & - & $0.1 \sim 1.4$ \\
\hline$\tau_{\mathrm{stp}}^{j, k}[\mathrm{~s}]$ & - & $3.0 \sim 4.5$ \\
\hline$\eta^{i, k}$ & - & 0.6 \\
\hline
\end{tabular}

\section{- PNNSSP}

ニューロン： $\tau_{\mathrm{m}}^{j}$

シナプス：前ニューロン番号，後ニューロン番号， $\tau_{\mathrm{d}}^{j, k}, w_{0}^{j, k}, \tau_{\mathrm{std}}^{j, k}, \tau_{\mathrm{stp}}^{j, k}$, 使用の可否

ここで，各 NN のパラメータの值は表 $1 ， 2$ のように設定 し， $w_{0}^{j, k}$ については $-1.00 \sim 1.00$ の範囲で 0.01 刻みの值, その他の值は表 $1 ， 2$ に示す範囲において 0.1 刻みの值で表 現する。また，シナプスの使用の可否は 0,1 の 2 值とし， 0 の場合は使用しない，1の場合は使用するものとする。こ れらのパラメータをく $3 \cdot 2$ 節で述べたように，ニューロンと シナプスについて順番に並べた 2 本の一次元配列を染色体 とする。例えば，Sigmoid NN におけるニューロンに関す る部分は, $\theta^{1}, \beta^{1}, \theta^{2}, \beta^{2}, \cdots$ というようにニューロン番 号毎に並んだ一次元配列であり，シナプスに関する部分は， $k, j, w_{0}^{j, k}, 1$ (使用)， $m, l, w_{0}^{l, m}, 0$ (未使用)，‥とい うようにシナプス毎に並んだ一次元配列である。これら 2 本の一次元配列は, 別々に遺伝操作を施す。なお， Radial $\mathrm{NN}$ については（3)，(4) 式からもわかるように，隠れ層 のニューロンにはパラメータがないため, ニューロンに関 する部分は，(2) 式のシグモイド関数を用いる入力層と出 力層のニューロンのパラメータを並べた一次元配列となる。 また，シナプスに関する部分は，入力層と隠れ層間のシナ プスと，隠れ層と出力層のシナプスでは染色体となるパラ メータが異なる。

続いて，ネットワークの構造について説明する。出力層 のニューロン数を 3 個とし，3 種の移動モジュールを選択 する際に用いる。入力層のニューロン数は，8 個の近接セ ンサに対応する 8 個， 1 個の視覚センサの解像度数に対応 する 12 個，1 ステップ前の出力層のニューロンの出力に対 応する 3 個の計 23 個とする，また，隠れ層は 1 層とし，隠

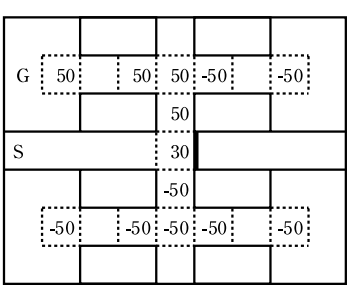

$\operatorname{mapA}$

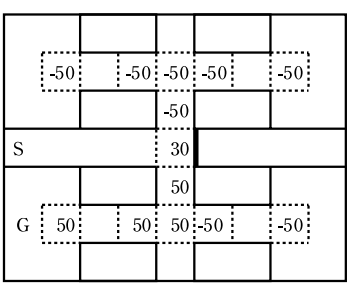

mapC

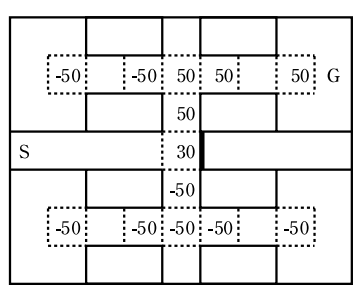

mapB

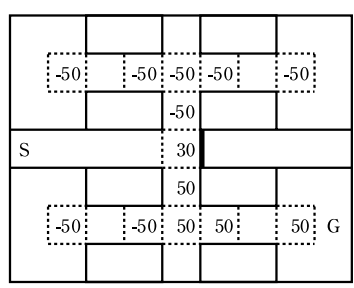

mapD
図 4 サブゴール，及び得点

Fig. 4. Sub goals, and their points.

れ層の初期ニューロン数は 12 個とする。ロボットはスター 卜地点からゴール地点に移動するまでに, 図 4 に示すサブ ゴール（点線で囲まれた部分）内に移動することで，同図 中の各サブゴールに割り当てられた值だけ得点を獲得する。 ゴール地点に到着すると規定ステップ数から，ゴール到着 に要したステップ数を引いた值を得点として獲得する。移 動モジュールの選択の際, 前進モジュールを選択した場合に 1 点獲得する。また, 壁に衝突した場合に 50 点を失う。各 環境で獲得した得点の平均值を適応度とする。さらに，本 実験ではネットワーク構造の最適化を GA で行うため，4 種類の環境でゴールに到達できた場合，つまりロボットが タスクを成功した場合，適応度を（18）式により計算する。

$$
F=W_{1} D_{\mathrm{n}}+W_{2} D_{\mathrm{s}}+f_{\text {ave }}
$$

ここで， $F$ はタスク成功時の適応度， $W_{1}, W_{2}$ は重みで あり，本実験では $W_{1}$ を $5, W_{2}$ を 1 とする。 $D_{\mathrm{n}}$ は隠れ 層の未使用ニューロン数, $D_{\mathrm{s}}$ は未使用シナプス数, $f_{\mathrm{ave}}$ は各環境で獲得した得点の平均值である。隠れ層の未使用 ニューロンとは入力層のニューロンからの接続がなく, 出 力層のニューロンへの接続がないニューロンとする。また, $w_{0}^{i, k}$ が 0 のシナプスは未使用シナプスとする。

実験における GA のパラメータを，表 3 のように設定す る。また，各パラメータは経験的に設定する。

本実験では環境を識別するための入力は各センサ以外に はない。また，スタート地点からみた各環境の違いは指示 板の色だけであり，ロボットは視覚センサの值により，環 境を識別しなければならない。さらに，視覚センサの值は 近接センサの值とは違い，值の大小関係には意味はない。 例えるならば，視覚センサの值は電話番号や郵便番号のよ うなものである。そのため, コントローラとして NN に求 められるものは, 特定の值 (PNN, 及び PNNSSP では值 がパルス頻度に変換されて入力されるので，特定のパルス 頻度）に反応するニューロンがなければならない。 
表 3 GA のパラメータ

Table 3. Parameters for GA.

\begin{tabular}{|l||c|c|c|c|}
\hline & Sigmoid NN & Radial NN & PNN & PNNSSP \\
\hline$G_{\max }$ & \multicolumn{4}{|c|}{600} \\
\hline$N$ & \multicolumn{4}{|c|}{40} \\
\hline$E_{\mathrm{n}}$ & \multicolumn{4}{|c|}{5} \\
\hline$C_{r}$ & \multicolumn{4}{|c|}{0.80} \\
\hline$C_{\mathrm{m}}$ & 0.015 & 0.010 & 0.008 & 0.006 \\
\hline
\end{tabular}

表 4 ゴール到達回数の分布とタスク成功率

Table 4. Distribution of quantity whose robot arrived to goal and success ratio.

\begin{tabular}{|c|c|c|c|c|c|c|}
\hline & \multicolumn{5}{|c|}{ Quantity of arrival at goal } & \multirow{2}{*}{$\begin{array}{c}\text { Success } \\
\text { ratio }\end{array}$} \\
\hline & 0 & 1 & 2 & 3 & 4 & \\
\hline Sigmoid NN & 0 & 0 & 16 & 10 & 4 & 0.13 \\
\hline Radial NN & 0 & 0 & 15 & 9 & 6 & 0.20 \\
\hline PNN & 0 & 0 & 3 & 6 & 21 & 0.70 \\
\hline PNNSSP & 0 & 0 & 0 & 3 & 27 & 0.90 \\
\hline
\end{tabular}

表 5 タスクが成功した試行の隠れ層の使用 ニューロン数, 及び使用シナプス数

Table 5. The number of neurons and synapses of hidden layer.

\begin{tabular}{|l||c|c|c||c|c|c|}
\hline \multicolumn{1}{|c||}{} & \multicolumn{3}{c||}{ Neurons } & \multicolumn{3}{c|}{ Synapses } \\
\cline { 2 - 7 } & max. & average & min. & max. & average & min. \\
\hline Sigmoid NN & 17 & 13.5 & 10 & 220 & 203.3 & 185 \\
\hline Radial NN & 15 & 11.2 & 8 & 229 & 182.7 & 149 \\
\hline PNN & 17 & 14.0 & 11 & 238 & 211.3 & 152 \\
\hline PNNSSP & 15 & 11.9 & 5 & 219 & 175.0 & 91 \\
\hline
\end{tabular}

$\langle\mathbf{4} \cdot \mathbf{1}\rangle$ 実験結果 図 5 に各世代に対する最良ロボッ 卜の適応度の変化（30 試行の平均）を示す。横軸は世代, 縦軸はロボットの適応度の值を表す。また, 図 6 に各世代 に対する最も適応度が高い最良ロボットのゴール到達回数 の変化（30 試行の平均）を示す。横軸は世代, 縦軸は各環 境でゴールに到達した回数を表す。すべての環境において， ゴールへ到達すると 4 になる。また, 表 4 に 30 試行のゴー ルに到達した回数の分布と，4種類の環境でゴールに到達 した試行の割合，つまり，タスクを成功した試行の割合を 示す。そして，表 5 にタスクを成功した試行において，各 試行の最良ロボットの隠れ層使用ニューロン数, 及び使用 シナプス数の最多，平均，最小数を示す。さらに, Sigmoid $\mathrm{NN}, \mathrm{PNN}$, 及び PNNSSP をコントローラとするのロボッ 卜の代表的な行動軌跡について, 図 $7 \sim 10$ に示す。

$\langle\mathbf{4} \cdot \mathbf{2}\rangle$ 考 察 図 5,6, 表 4 より, Sigmoid NN, Radial NN に比べ, PNN, PNNSSP を用いるコントロー ラの方が構築がしやすく，性能が良いことがわかる。

つぎに, 図 8 の Sigmoid NN をコントローラとするロ ボットの行動軌跡例と, 図 10 の PNNSSP をコントローラ とするロボットの行動軌跡例を比較する。どのロボットも mapA と mapB を走行する場合, スタート地点から指示 板までは前進し，その後左折する。ここで注目すべき点は 左折する位置である。Sigmoid NN をコントローラとする 場合，左折するときの軌道が違う。mapA では左側の壁沿

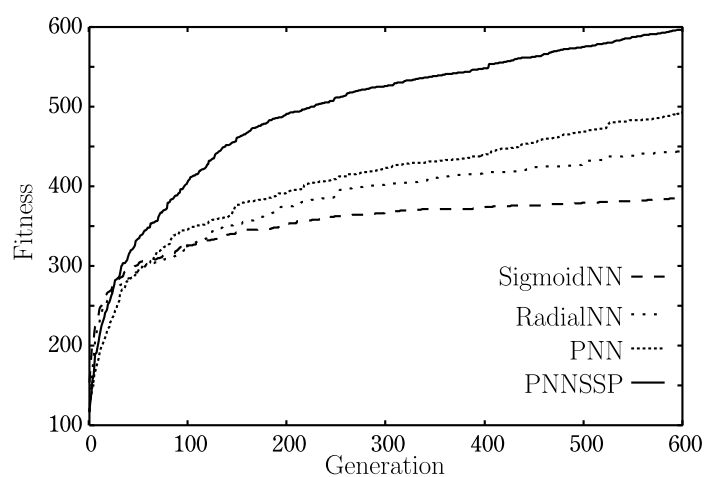

図 5 各世代に対する最良個体の適応度の変化 (30 試行の平均)

Fig. 5. Generation characteristic of elite individual fitness (average of 30 trials).

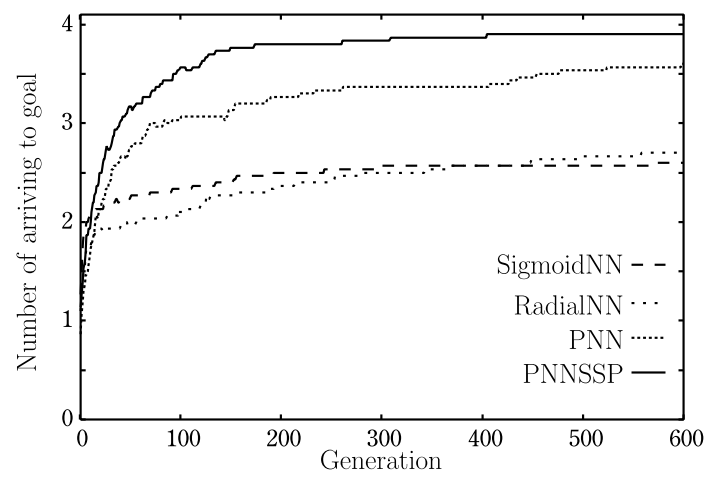

図 6 各世代に対するゴール到達回数の変化（30 試行の平均)

Fig. 6. Generation characteristic of quantity whose robot arrived to goal (average of 30 trials).

いを走行し，mapBでは右側の壁沿いを走行する。対して， PNNSSP をコントローラとする場合は, mapA と mapB の左折するときの軌道が同じである（PNN も同様の軌跡を 示す)。これは, mapC と mapD を走行する際も同様のこ とがいえる。また, 図 7 の Sigmoid NN がコントローラの 場合, mapA と mapBで左折するときに同じ軌道を通過す ると, mapA と mapB を識別できずに, タスクを失敗して する。これは, ネットワークへ入力される時系列パターン に対する Sigmoid NN の処理能力が低いことが原因である と考えられる（Radial NN も同様のことがいえる）。 mapA と $\mathrm{maB}$ において, 指示板を通過した直後のロボットの視界 からはゴール地点が見えない。そのため, ネットワークの 内部状態に指示板の色の違いよる差異が左折後もなければ, mapA と mapB で同じ軌道を通過することができない。し かし, Sigmoid NNの場合，ネットワークの入力に 1 ステッ プ前のネットワークからの出力があるとしても, 指示板の 色の違いよる内部状態の差異を表現することが難しいため, 左折，及び右折する前に（指示板が見えているうちに）環 境を識別して軌道を変えることで，環境毎に左折及び右折 後の軌道を変化させていると考えられる。一方, PNNSSP をコントローラとする場合は, ネットワークの内部状態に 


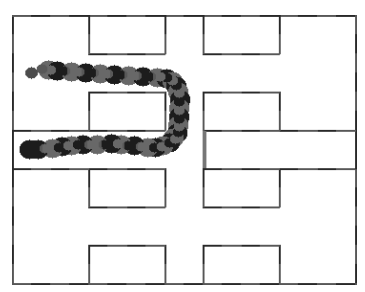

mapA

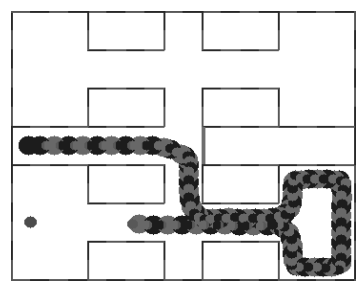

mapC

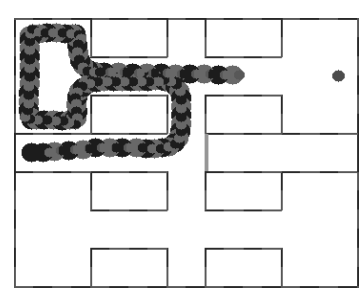

mapB

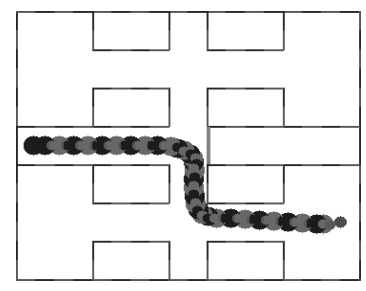

$\operatorname{mapD}$
図 7 コントローラが Sigmoid NN の行動軌跡 (タスク失敗例，適応度 389)

Fig. 7. Trace of robot whose controller is Sigmoid NN. Task is failuer. Fitness is 389.

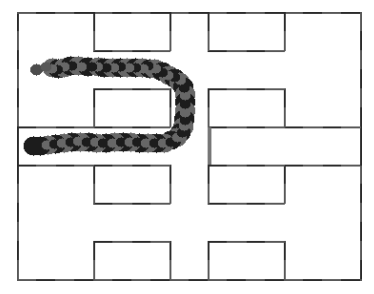

$\operatorname{mapA}$

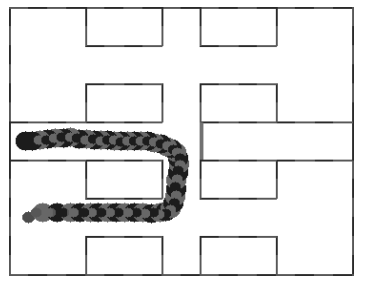

mapC

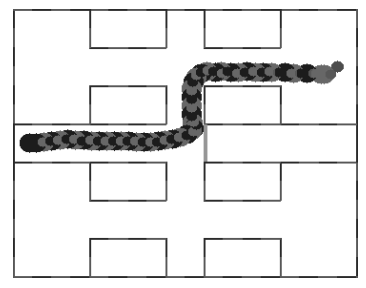

mapB

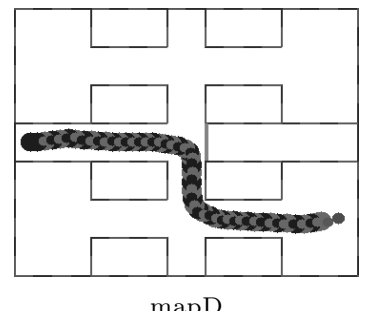

$\operatorname{mapD}$
図 8 コントローラが Sigmoid NN の行動軌跡 (タスク成功例, 適応度 552)

使用シナプス数: 190 個, 使用隠れ層ニューロン数: 14 個

Fig. 8. Trace of robot whose controller is Sigmoid NN. Task is success. Fitness is 552. The number of hidden layer's neurons is 14 and that of synapses is 190.

指示板の色の違いよる差異を表現できるため, 左折，及び 右折する時の軌道が同じでも，左折及び右折後に違う移動 モジュールの選択が可能になると考えられる。

続いて, 図 9 のPNN をコントローラとする場合の行動 軌跡と図 10 の PNNSSP をコントローラとする場合の行動 軌跡を比較する。PNNをコントローラとする場合，一応夕 スクを成功している。しかし，停止したり，無駄なモジュー ル選択を行うため軌跡は蛇行し滑らかでない。これに対し て, 図 10 の PNNSSP をコントローラとする場合の行動 軌跡は，少ないモジュール選択回数でゴールに到達する。 本実験では, 前進, 右壁沿い, 左壁沿いモジュールを選択

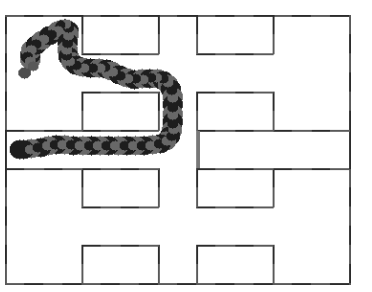

$\operatorname{mapA}$

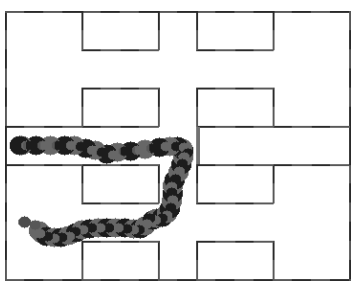

mapC

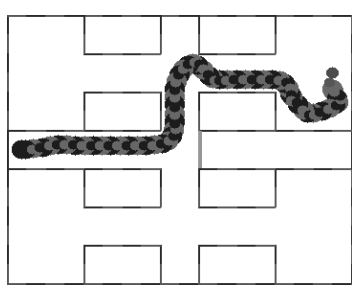

$\operatorname{mapB}$

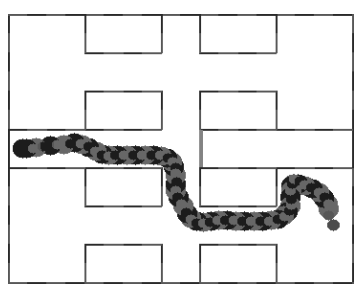

mapD
図 $9 \mathrm{PNN}$ をコントローラとする場合の行動軌跡 (夕スク成功例, 適応度 512)

使用シナプス数:199 個, 使用隠れ層ニューロン数: 14 個

Fig. 9. Trace of robot whose controller is PNN.

Task is success. Fitness is 512. The number of hidden layer's neurons is 14 and that of synapses is 199.

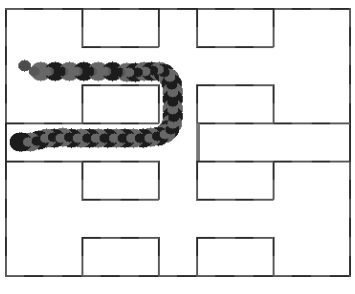

mapA

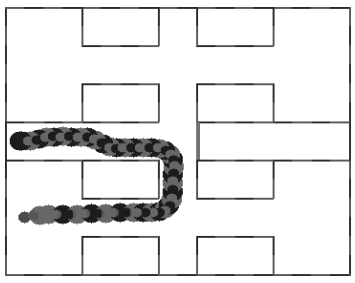

$\operatorname{mapC}$

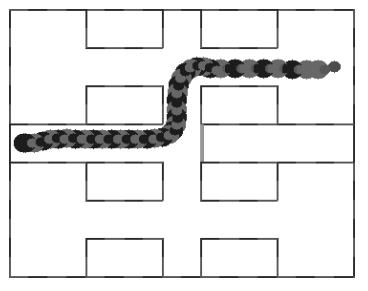

mapB

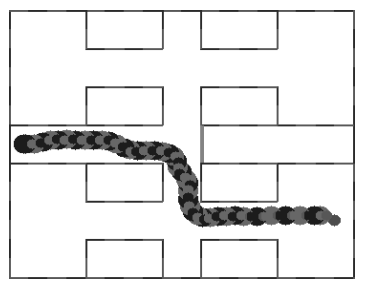

$\operatorname{mapD}$
図 10 コントローラが PNNSSP の行動軌跡 (夕スク成功例, 適応度 746)

使用シナプス数:140 個, 使用隠れ層ニューロン数:9 個

Fig. 10. Trace of robot whose controller is PNNSSP. Task is success. Fitness is 746. The number of hidden layer's neurons is 9 and that of synapses is 140 .

することによりロボットは移動する。例えば右壁沿いの移 動モジュールを選択した場合，本実験で使用したどの NN を用いても右側の壁沿いを走行し，コーナーがある場合は 同じ軌跡で回る。これは, 図 8 のコントローラが Sigmoid $\mathrm{NN}$ のタスク成功時の行動軌跡例と, 図 10 のコントローラ がPNNSSP の行動軌跡例で，コーナーを回るときや（右, 左壁沿いモジュールを選択), ゴールに向かうとき（前進モ ジュールを選択）の軌跡がほぼ同じであることからもわか る。つまり, 適切なタイミングで適切なモジュールを選択 
することができれば，どの NN を用いても同じ軌跡をとる ことになる。また, PNN と PNNSSP の各ニューロンの発 火状況を自律移動ロボットシミュレータで比較したところ, PNNの方が発火数が多いことがわかっている。PNNをコ ントローラとする場合に無駄なモジュール選択を行うのは, 出力層のニューロンの発火の制御がうまくいかず，出力層 のニューロンの発火数が多くなり，適切なタイミングで適 切なモジュールを選択できていないためであると考えられ る。したがって, PNNのコントローラよりもPNNSSP の コントローラの方が性能が良いといえる。

さらに, 構築されたネットワークの構造の複雑さを比較す る。表 5 より, PNNSSP がシナプス数及びニューロン数が 他のネットワークに比べて少なく，単純な構造でコントロー ラが構築できることがわかる。また，表 4 より, PNNSSP は PNN に比べて調節するパラメータ数が多いにもかかわ らず，タスクを成功するコントローラが構築できた試行が 最も多い。

以上のことから，PNNSSP のコントローラは他のネット ワークのコントローラよりも, 単純な構造でありながら, 構築しやすく，性能がよいことが明らかであり, PNNSSP の工学的応用として, PNNSSP を自律移動ロボットのコン トローラに用いることは可能であると考えられる。

\section{5. むすび}

本論文では，Sigmoid NN，Radial NN，PNN，及び我々 が提案したPNNSSP を自律移動ロボットのコントローラ に用いる場合について，各パラメータ，及びネットワーク 構造の調整に GA を用いてコントローラを構築し, 構築の しやすさ，コントローラの性能，及びネットワーク構造に ついて計算機による比較実験を行った。計算機実験の結果, Sigmoid NN，及び Radial NN で構築されたコントローラ よりも PNN, 及び PNNSSP で構築されたコントローラの 方が構築しやすく, 性能が優れていることが明らかとなっ た。また，PNNよりもPNNSSP の方がニューロン数，及 びシナプス数が少なくネットワーの構造が単純であること が明らかとなった。

今後の課題として，本論文ではシングルエージェントで 静的な環境において実験を行った。今後は，マルチエージェ ントで動的な環境において実験を行う必要がある。また， $\mathrm{NN}$ の入力であるセンサの雑音に対する頑健性に対する検 証を行う必要がある。

(平成 18 年 10 月 24 日受付, 平成 19 年 2 月 27 日再受付)

\section{文献}

（1）北野宏明：「遺伝的アルゴリズム」, 産業図書株式会社 (1993)

(2) W. Gerstner, R. Kempter, J.L.van Helmmen, and H. Wagner: "A neuronal learning rule for sub-millisecond temporal coding", Nature, Vol.383, pp.76-78 (1996)

(3) W. Maass and C.M. Bishop: "Pulsed Neural Networks," The MIT Press (2001)
(4) W. Gerstner and Werner M. Kistler: "Spiking Neuron Models", Cambridge University Press (2002)

(5) M. Motoki, T. Hamagami, S. Koakutsu, and H. Hirata: "A pulse neural network with regulator of short-term transmission efficiency", IEICE Technical Report, NC2002-39, pp.5560 (2002) (in Japanese)

元木 誠・小圷成一・濱上知樹 - 平田廣則 :「短期的な伝達効率の 調節機構を持つパルスニューラルネットワーク」，信学技術研報， NC02-39, pp.55-60 (2002)

(6) M. Motoki, S. Koakutsu, and H. Hirata: " A pulse neural network incorporating short term synaptic plasticity for engineering applications", International Journal of Innovative Computing, Vol.1, No.3, pp.417-428, (2005)

（7） 久野 宗 監修：「脳を知る」，秀潤社 (1999)

(8) M. Hisada, Y. Sakumura, and S. Ishii: "Depressing synaptic model based on vesicle release probability", IEICE Technical Report, NC2000-136, pp.63-70 (2001) (in Japanese) 久田正樹・作村勇一・石井 信 :「シナプス小胞の放出確率による減 衰シナプスモデル」信学技術研報, NC2000-136, pp.63-70 (2001)

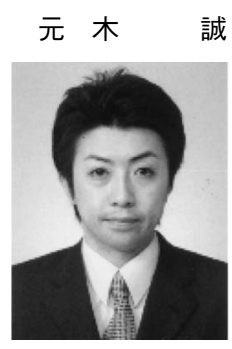

誠（正員） 1977 年 8 月 10 日生。 2005 年, 千葉大 学大学院自然科学研究科人工システム科学専攻博 士後期課程修了。同年 10 月, 名古屋工業大学大 学院工学研究科 産学官連携研究員。2006 年, 関 東学院大学工学部講師となり現在に至る。パルス ニューラルネットワークの研究，及び，その応用 に関する研究に従事。博士 (工学)。電子情報通 信学会会員。

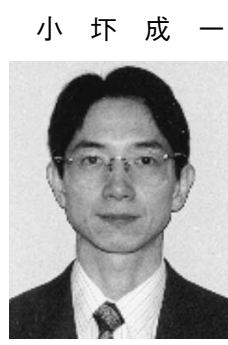

(正員) 1964 年 7 月 7 日生。92 年，千葉大学大 学院自然科学研究科生産科学専攻博士課程修了。 同年, 千葉大学工学部助手, 97 年同助教授, 同年 同大学院自然科学研究科助教授, 2007 年同大学院 工学研究科准教授となり現在に至る。94 95 年, カリフォルニア大学サンタクルズ校客員研究員。 VLSI レイアウト, 確率的最適化手法, ニューラル ネットワークの研究に従事。博士 (工学)。IEEE, INNS, 電子情報通信学会, 計測自動制御学会会員。

平 田 廣 則 （正員） 1948 年 6 月 2 日生。 76 年，東京工業

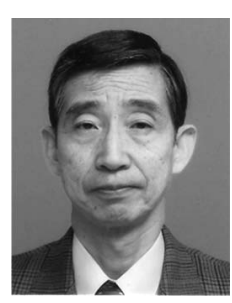
大学大学院電気工学専攻博士課程修了。同年, 千 葉大学工学部助手, 81 年同助教授, 94 年同教授, 97 年同大学院自然科学研究科教授, 2007 年同大 学院工学研究科教授となり現在に至る。大規模シ ステムのモデリング, 解析と設計, 特に生態シス テム, VLSI レイアウト, 並びに分散システムの 基礎的理論に興味を持つ。工学博士。2001 年電 気学会業績賞受賞。IEEE(Fellow), INNS, 電子情報通信学会, 情報 処理学会, 計測自動制御学会, システム制御情報学会, 人工知能学会, 日本数理生物学会会員。 